\title{
Porosity and Rock-Typing in Hydrocarbon Reservoirs Case Study in Upper Member of Dalan Formation in Kish Gas Field, South of Zagros, Iran
}

\author{
Ali-Akbar Irajian1, Kamaladdin Bazargani-Guilani2*, Rahim Mahari' ${ }^{3}$, Ali Solgi1 \\ ${ }^{1}$ Department of Geology, College of Science, Science and Research Branch, Islamic Azad University, Tehran, Iran \\ ${ }^{2}$ School of geology, University College of Science, University of Tehran, Tehran, Iran \\ ${ }^{3}$ Department of Geology, Faculty of Science, Tabriz Branch, Islamic Azad University, Tabriz, Iran \\ Email: *kbazargani@ut.ac.ir
}

Received 17 May 2016; accepted 21 June 2016; published 24 June 2016

Copyright (C) 2016 by authors and Scientific Research Publishing Inc.

This work is licensed under the Creative Commons Attribution International License (CC BY). http://creativecommons.org/licenses/by/4.0/

\section{(c) (i) Open Access}

\begin{abstract}
To estimate the volume of oil and gas in the hydrocarbon reservoirs, the rock-typing must be considered. The volume and type of available space in the reservoir rocks (porosity) and the ease of hydrocarbons flow (permeability) are important in the classification of rock-types. In the field study, touching-vug Porosities (intergranular, intercrystalline and brecciate) increase the total porosity and form high quality rock-types, on the other side, separated-vug porosities (such as moldic, intraparticle and vuggy) increase the total porosity but do not play a large role in the production of hydrocarbon. In this paper, based on the SCAL data (Special Core Analysis) and according to amount of irreducible water saturation (Swir) and capillary pressure, the reservoir rocks are divided into 4 classes including Reservoir Rock-Types 1 to Reservoir Rock-Types 4 (RRTs-1 to RRTs-4). By study of the prepared thin sections, we investigated the role of porosity in the rock-typing. Among the rock-types, category 1 is the best type-reservoir and category 4 is non-reservoir. Probably, the latest diagenetic process determines the quality rocks, not sedimentary environments.
\end{abstract}

\section{Keywords}

Porosity, Rock-Typing, Hydrocarbon Reservoirs, Dalan Formation, Zagros

${ }^{*}$ Corresponding author.

How to cite this paper: Irajian, A.-A., Bazargani-Guilani, K., Mahari, R. and Solgi, A. (2016) Porosity and Rock-Typing in Hydrocarbon Reservoirs Case Study in Upper Member of Dalan Formation in Kish Gas Field, South of Zagros, Iran. Open Journal of Geology, 6, 399-409. http://dx.doi.org/10.4236/ojg.2016.66035 


\section{Introduction}

Depositional and diagenetic processes control the fluid movement and its saturation behavior by forming pores and changing them in the reservoir rocks [1]. Sedimentary and petroleum geologists widely use porosity classification of [2]. This classification is tightly based on sedimentary fabric and so can predicts the types of spaces (porosity) with respect to the depositional provenance or diagenesis evolution. The mentioned classification system is especially useful for study of porosity evolution and exploration of oil and gas. The classification of [3] and more recently ones [4] [5] are used among petrophysist and reservoir engineers due to the direct relationship of this type of classification to pore geometry and fluid properties.

Study of the reservoir rock-types (RRTs) is very important to estimate the recoverable hydrocarbon reserves [1]. Conventional static method in the determination of reservoir rock-types is evaluation of textural properties and porosity types of reservoir rocks and their relationships with petrophysical properties (permeability and saturation) [6] [7]. So study of porosity type and permeability in different parts of hydrocarbon reservoirs is very important for oil and gas production management. So it seems that study of reservoir rock type helps for more hydrocarbons production in oil and gas fields. Many researcher works on reservoir rock types among the rest: [6]-[10].

In this paper we imply to the types of porosity and their effect on the formation of reservoir rock-types, and the results of the rock-typing investigated on reservoir layers of the Upper Member of the Dalan Formation in a large gas field in the northern Persian Gulf.

\section{Materials and Methods}

In this study, 554 thin sections (approximately one thin section per $30 \mathrm{~cm}$.) gamma and sonic logs have been studied. All thin sections were examined by Alizarin Red-s for separation of dolomite from calcite. For petrophysical study have been used from Special Core Analysis (SCAL data) including irreducible water saturation (Swir), capillary pressure, and permeability data. Log-plot (version 6) was utilized for drawing the litho-stratigraphic column.

\section{Geology of Persian Gulf}

Due to abundant and huge hydrocarbon reservoirs in the Persian Gulf, the geological and tectonic activities have been considered during the recent decades. The Persian Gulf has formed by development of the mouth of the West Sea of Oman about 30 million years ago. Approximately, 60 percent of hydrocarbon reservoirs in the Persian Gulf (including the gas fields) have been created as a result of the salt tectonic activity [11]. In addition to salt tectonic activity, this Gulf is also affected by the number of plates and faults (African plate, Arabian plate, Asian plate, Zagros suture zone, Red Sea rift and Gulf of Aden rift), affecting existed structures (Figure 1). Geoloically, the Persian Gulf (and gas fields under discussion) is located in the Alpine-Himalayan Mountains belt, and is a part of tectono-stratigraphic unit of The Zagros Mountains, located in the south of this unit in the northern Persian Gulf [12] [13].

\section{Geology of Kish Gas Field}

In the drilled wells of the Kish gas field, thickness of the Upper Dalan Members changes from $229 \mathrm{~m}$ (Well A) to $277 \mathrm{~m}$ (wells B) and this member has two sub-members including K3 and K4 (Figure 2). The Upper Dalan Member is conformably underlain by the Nar Member and covered by the Kangan Formation (permo-triassic boundary) as an unconformity. General lithology of the Upper Dalan Member is dolomite, dolomitic limestone, limestone, some anhydrites and shale.

\section{Porosity in the Upper Dalan Member}

Types of porosity and pore throat between them plays important role in hydrocarbons' storage and production [14] [15].

Porosity in the carbonate rocks can be divided into two major groups; interparticle porosities and vug porosities [4] [5] [16].

Vug porosity is also divided into two sub-groups of touching-vug porosities and separate-vug porosities. 


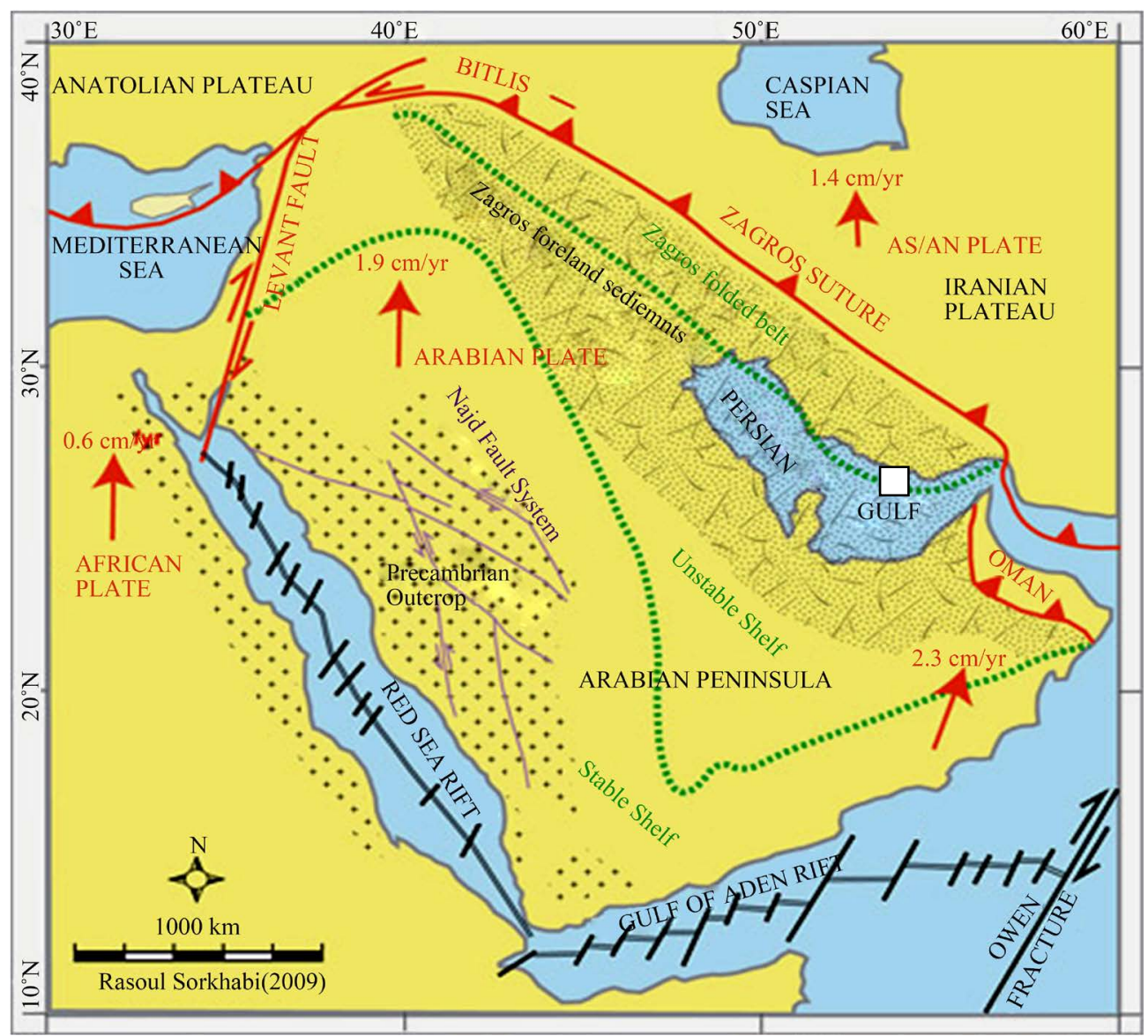

Figure 1. Location of the Persian Gulf related to the Arabian plate and the rate and trend of plates and main faults controlling salt domes. White square shows the position of Kish gas field.

\subsection{Interparticle Porosities}

In the sedimentary environment, interparticle porosity generally occurs in the carbonate sediments without mud. Interparticle porosity is divided into intercrystalline and Intergranular porosity. This porosity group is very useful for permeability of reservoir [4] [16].

\subsubsection{Intercrystalline Porosity}

This type of porosity is formed in the existing space among the dolomite crystals (Figure 3(a)) and their geological origin is from sabkha to open marine. This porosity is one of the best spaces for gas reserves in the gas field.

\subsubsection{Intergranular Porosity}

This type of porosity usually is developed in the spaces among ooid allochems and skeletal grains in the K3 and K4 sequences (Figure 3(b)).

\subsection{Vug Porosity}

\subsubsection{Touching-Vug Porosities}

These groups include fracture, shear, vuggy and fenestral porosities. The group is usually non-fabric selective. Porosities of the group are usually are connected together to form a network and could be helpful for permeability of gas reservoirs [4] [16]. In the Member, brecciated porosity is more important.

1) Brecciated porosity

Brecciating of carbonate rocks may occur in the following conditions: collapse of evaporate and carbonate 


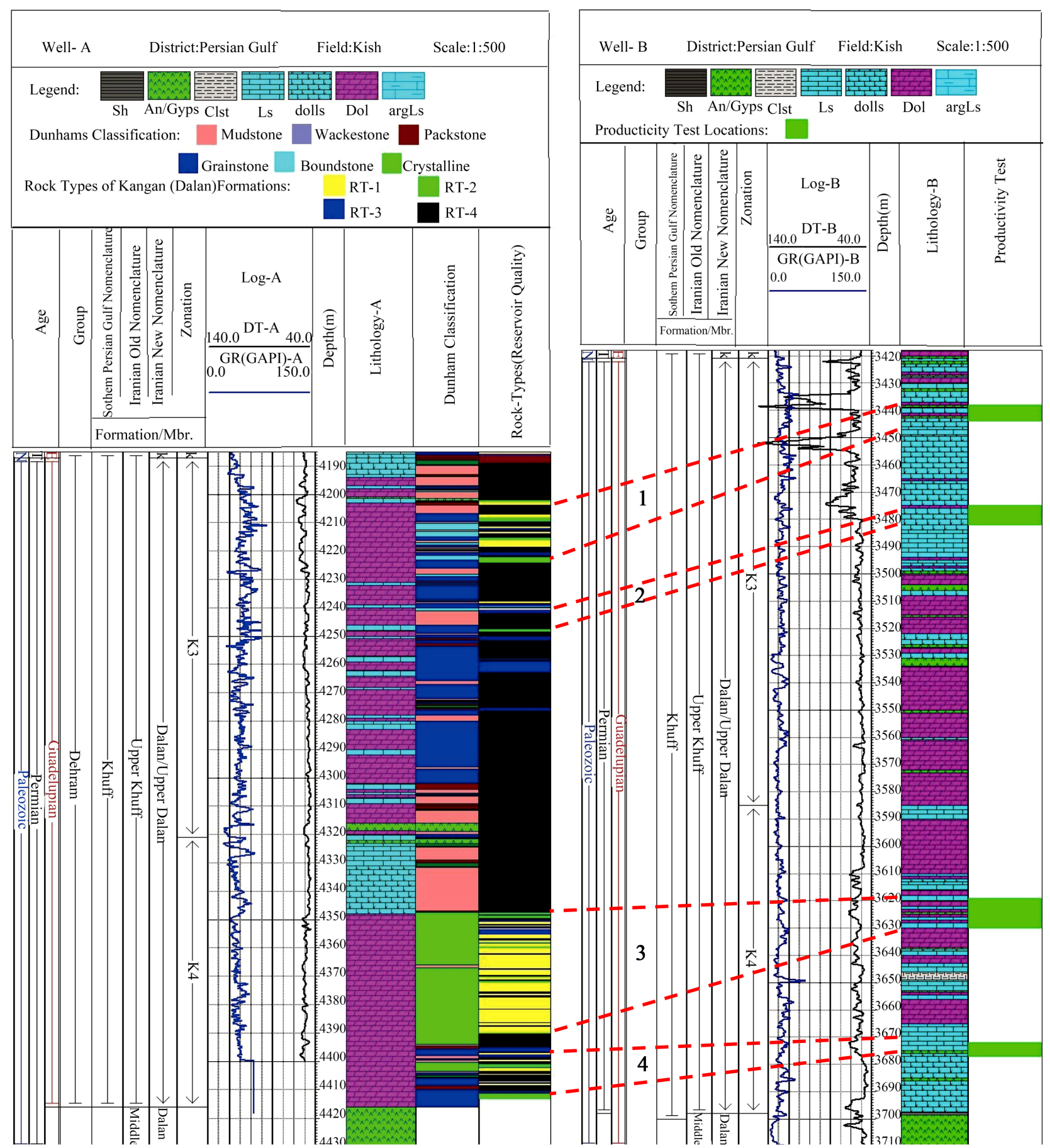

Figure 2. Litho-stratigraphic column of the upper dalan member in two Wells-A \& B. In the column, numbers 1 to 4 show correlations of reservoir layers between Well-A \& B.

rocks in respect to the dissolution and other similar phenomena. This type of porosity is not very abundant in the Upper Dalan Member but it makes the reservoir rock with high quality (Figure 3(c)).

\subsubsection{Separate-Vug Porosities}

Generally, these kinds of porosities include moldic, intraparticle and shelter types. In this group, porosity is usually seen as separate vugs or slightly connected pores (indirectly. These types of porosities are fabric selective 

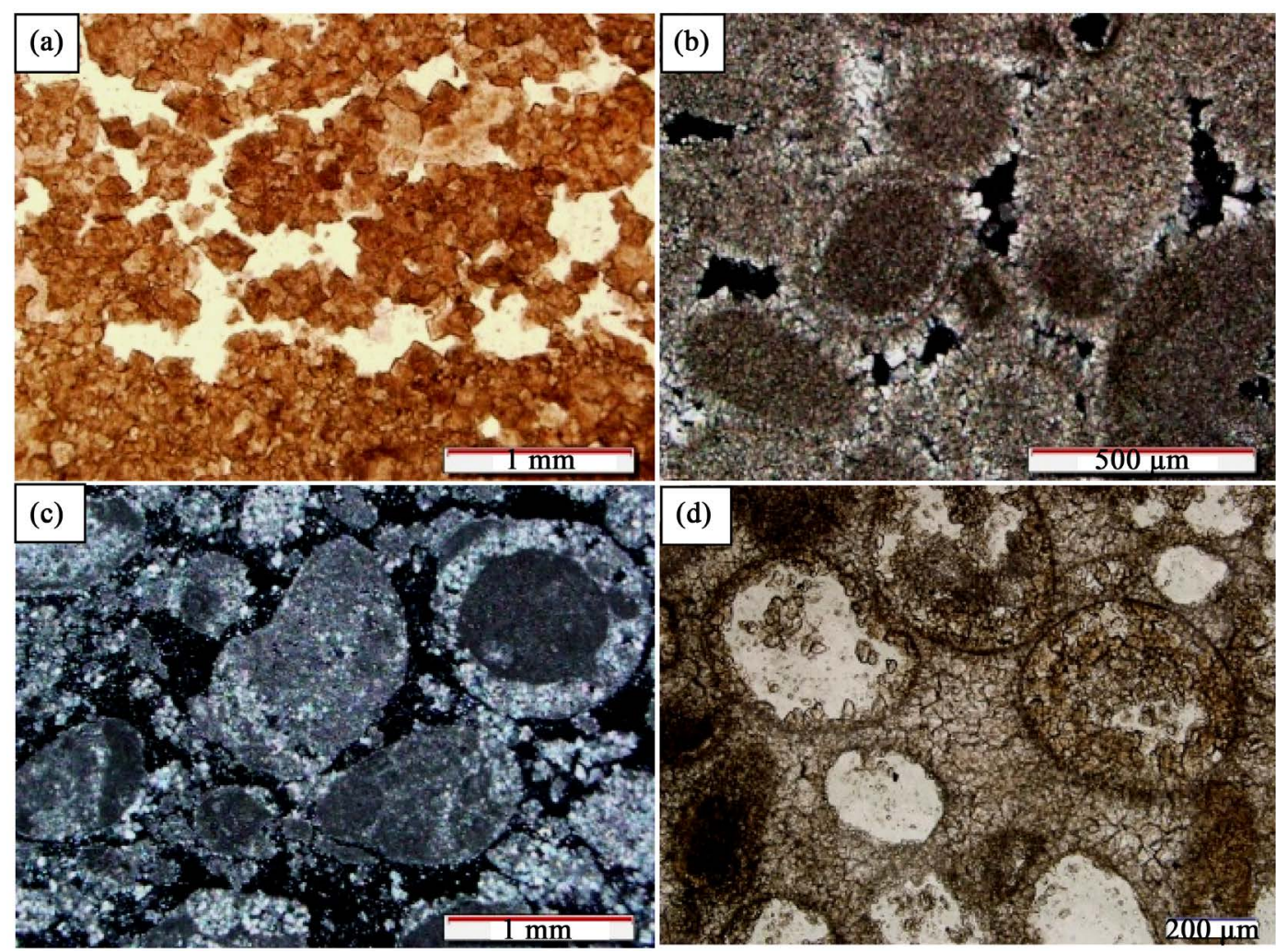

Figure 3. Types of porosity. (a) Intercrystalline porosity. This porosity occurs in spaces among dolomite crystals in a dolostone. (b) Intergranular porosity formed in spaces among ooids. (c) Brecciated porosity in a skeletal-ooid grainstone. (d) moldic porosity occurs by dissolution of ooids.

and usually increase the reservoir porosity not the reservoir permeability [4] [16]. In the studied rocks, the moldic porosity is more important than the other types.

1) Moldic porosity

Moldic porosity is the most abundant porosity in the Upper Dalan Member. It usually seen in ooids and skeletal facies (oomolds and biomolds) (Figure 3(d)). The porosity usually occurs as a selective dissolution process by dissolving of fossils and allochems. The porosity may occur during the early diagentic stage but it is generally the result of the secondary diagenesis in meteoric environment with water under-saturation of carbonate ions accompanied with the high water flow [17].

\section{Reservoir Rock-Types (RRTs)}

As mentioned earlier, investigation the type of porosity and permeability are very important in different parts of hydrocarbon reservoirs for the management of oil and gas production. Conventional static method in the determination of a reservoir rock types are as follows: Study of the textural properties and porosity types of reservoir rocks and their relationships with petrophysical properties (permeability and water saturation) of the reservoir rocks [7]. It is important that the characteristics of carbonate rocks (texture and porosity) are continuously changed by changing the diagenetic processes. So it also affects on petrophysical properties of the reservoir rock. The static classification of reservoir rock types is depended on the permeability and irreducible water saturation (Swir). Based on these two factors, accompanied with the porosity, 4 reservoir rock types (RRTs-1 to RRTs-4) were identified for the Upper Dalan Members (Table 1).

\subsection{Rock Type 1 (RRTs-1)}

1) Dolomite (dolostone, crystalline carbonate): This rock type is composed of euhedral dolomite crystals with sucrosic texture, having very good developed intercrystalline porosity (Figure 4(a)). Because of very low Swir 

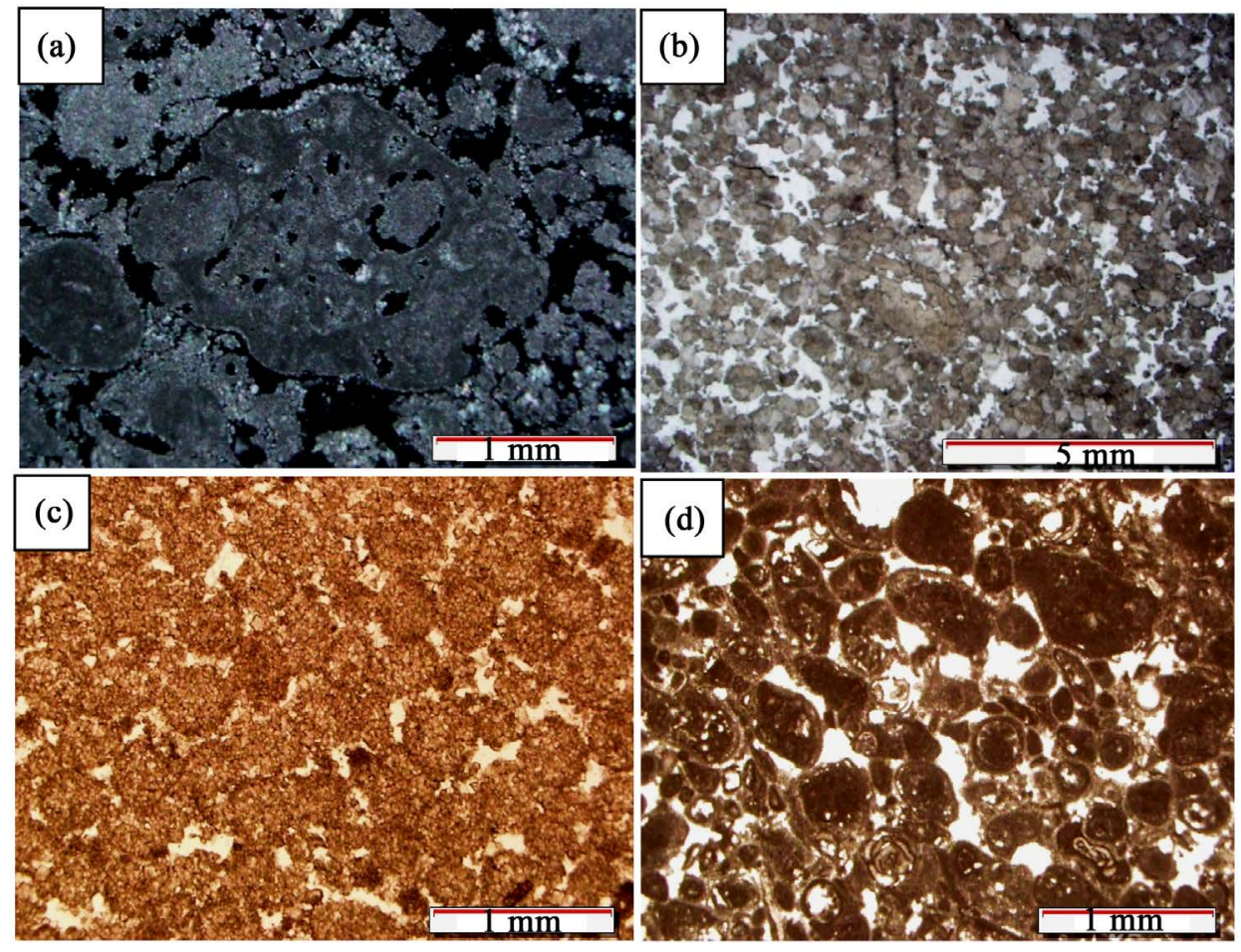

Figure 4. types of RRTs-1 \& 2: (a) A dolostone consists of good preserved intercrystalline porosity (black color) that creates sucrosic texture. (b) Bioclastic-ooid grainstone with brecciated porosity (black color). (c) Dolo-grainstone with intergranular porosity and channel porosity (arrow). Quasi-ooids (molds) is occupied by dolomite. (d) Dolo-grainstone showing intergranular, intragranular, and moldic porosities.

and very high permeability, this rock type is the best type among the other rock types (Table 1, row 1 and Plot $1(\mathrm{a}))$.

2) Bioclastic-ooid grainstone: This rock type is composed of skeletal debris and quasi-ooid, having brecciated porosity (Figure 4(b)). After cementing, the rock was brecciated and good permeability created for fluid flow. Because of very low Swir and very high permeability, this rock type is the best type among the other rock types (Table 1, row 1 and Plot 1(a)).

\subsection{Rock Type 2 (RRTs-2)}

1) Dolo-grainstone: This rock type is formed from quasi-ooid and neomorphic dolomite, having intercrystalline and channel porosities (Figure 4(c)). The dolomite crystals are mostly sub-hedral and anhedral and have filled the inside of ooids and molds. This rock type is suitable for hydrocarbor reservoir. Interparticle porosity is one of the best types for fluid transmission in petroleum and gas reservoir. Because of low Swir and high permeability, this rock type is suitable among the other rock types (Table 1, row 2 and Plot 1(b)).

2) Dolo-grainstone: This rock type is composed of skeletal debris, alga, quasi-ooid and interparticle, intraparticle, and moldic porosities (Figure 4(d)). Moldic porosity acts as a trap for hydrocarbor fluid but based on porethrout connection between the porosities (intraparticle and moldic porosities) with interparticle porosity can neutralize this effect (trap the fluids). This rock type is suitable among the other rock types for gas reservoir and fluid transmission (Table 1, row 2 and Plot $1(\mathbf{b})$ ).

\subsection{Rock Type 3 (RRTs-3)}

1) Dolo-grainstone: This rock type composed of quasi-ooid and posses vuggy and interparticle porosities. Quasi-ooids is occupied by dolomite cements (Figure 5(a)). Most of spaces among quasi-ooids were filled by anhydrite so the rock has low permeability and high Swir (Table 1, row 3 and Plot 2(a)). This rock type cannot 
Table 1. The average values of irreducible water saturation (Swir), permeability (K) and porosity (P \& PHI) in the formation of reservoir rocks.

\begin{tabular}{|c|c|c|c|c|c|c|c|c|}
\hline $\begin{array}{l}\text { Rock } \\
\text { Type }\end{array}$ & $\begin{array}{l}\text { Swir } \\
(\%)\end{array}$ & $\begin{array}{c}\mathbf{P} \\
(\mathbf{8 5} \%)\end{array}$ & $\begin{array}{c}\mathbf{P} \\
(\mathbf{6 0} \%)\end{array}$ & $\begin{array}{c}\mathbf{P} \\
(35 \%)\end{array}$ & $\begin{array}{c}P \\
(16 \%)\end{array}$ & K (MD) & $\begin{array}{l}\text { PHI } \\
\text { (\%) }\end{array}$ & Dominant fabric and pore types \\
\hline 1 & 8.8 & 1.2 & 3.8 & 15.3 & 221.7 & 261.7 & 13 & $\begin{array}{l}\text { Grainstone with brecciate porosity and } \\
\text { dolomite with well-preserved } \\
\text { intercrystalline porosity. }\end{array}$ \\
\hline 2 & 15.4 & 2.9 & 8.2 & 26.1 & 205.7 & 60.6 & 13.6 & $\begin{array}{l}\text { Dolo-grainstone with intercrystalline } \\
\text { and channel porosity and Cd1 type } \\
\text { and grainstone with interparticle and } \\
\text { moldic porosities }\end{array}$ \\
\hline 3 & 17.4 & 2.4 & 6 & 25.7 & 260.8 & 11.9 & 8.2 & $\begin{array}{l}\text { Dolo-grainstone with vuggy and } \\
\text { interparticle porosities and anhedral } \\
\text { dolomite type and over-dolomitization }\end{array}$ \\
\hline 4 & 35.6 & 4.4 & 85.3 & 346 & $>800$ & 3.2 & 9.8 & $\begin{array}{l}\text { Grainstone with oo \& bio-moldic porosities, } \\
\text { more of it occupied with dolomite, calcite } \\
\text { and anhydrite. Grainstone with various } \\
\text { porosity that all of it occupied by } \\
\text { pore-filling anhydrite and calcite. }\end{array}$ \\
\hline
\end{tabular}
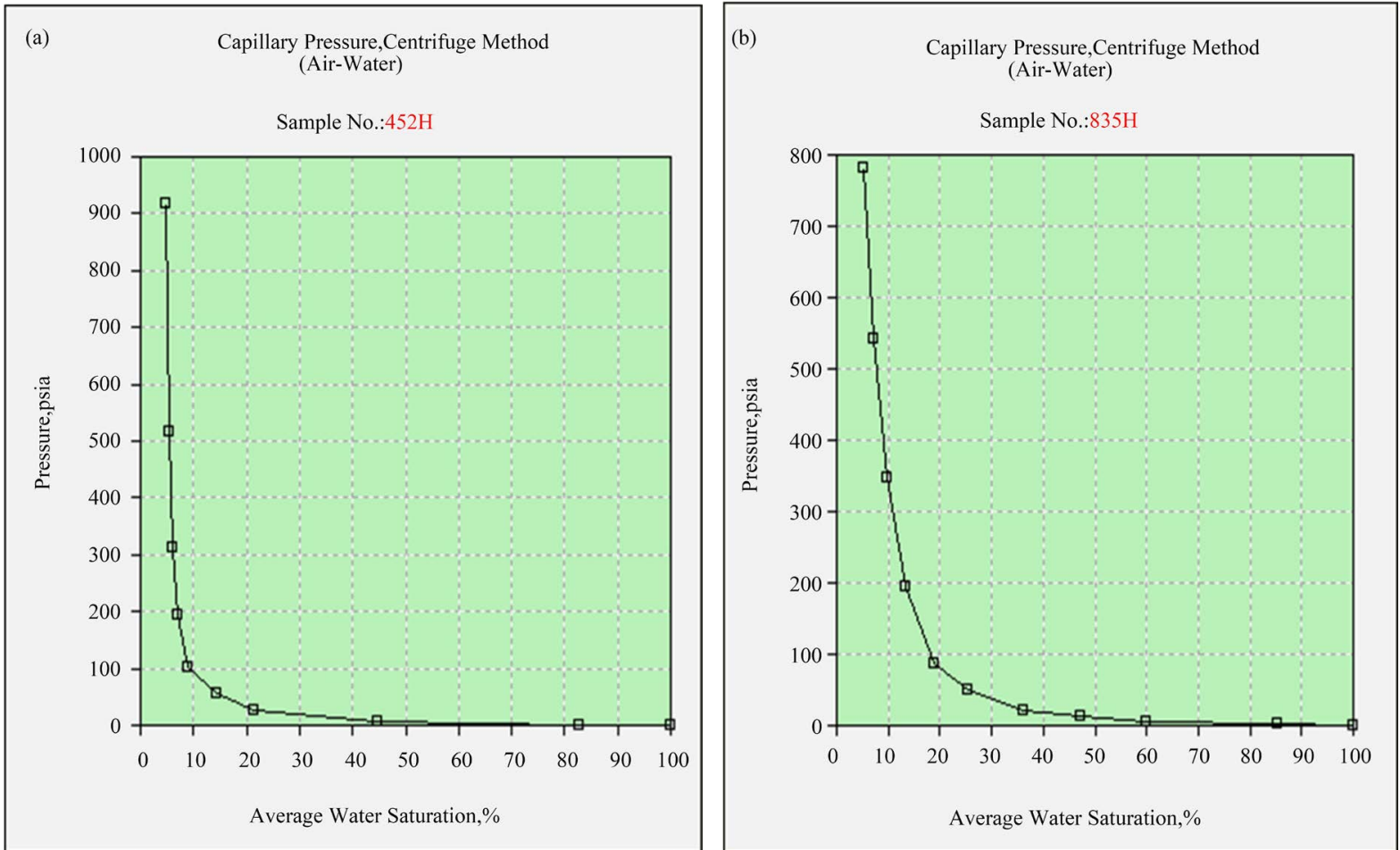

Plot 1. Cross plots show release the amount of water saturated inside the porosities into RRTs vs. the amount of capillary pressure under laboratory conditions. (a) \& (b). As can be seen in these plots, with increasing about 100 psi pressure, releases up to $90 \%$ of the water saturated trapped in porosity of the RRTs-1 \& 2, it is mean, less than $10 \%$ capillary water remains in porosity and porethrotes. The plots indicate the high permeability and low Swir in RRTs-1 \& 2 .

be a good reservoir.

2) Dolomite (dolostone, crystalline carbonate): This rock type consists of dolomite with a little intercrystalline porosity (Figure 5(b)). Most of dolomite crystals are platy and sub-hedral. Over-dolomitization process occurs in this rock, having high Swir and low permeability (Table 1, row 3 and Plot 2(a)). This rock type cannot be suitable reservoir. 

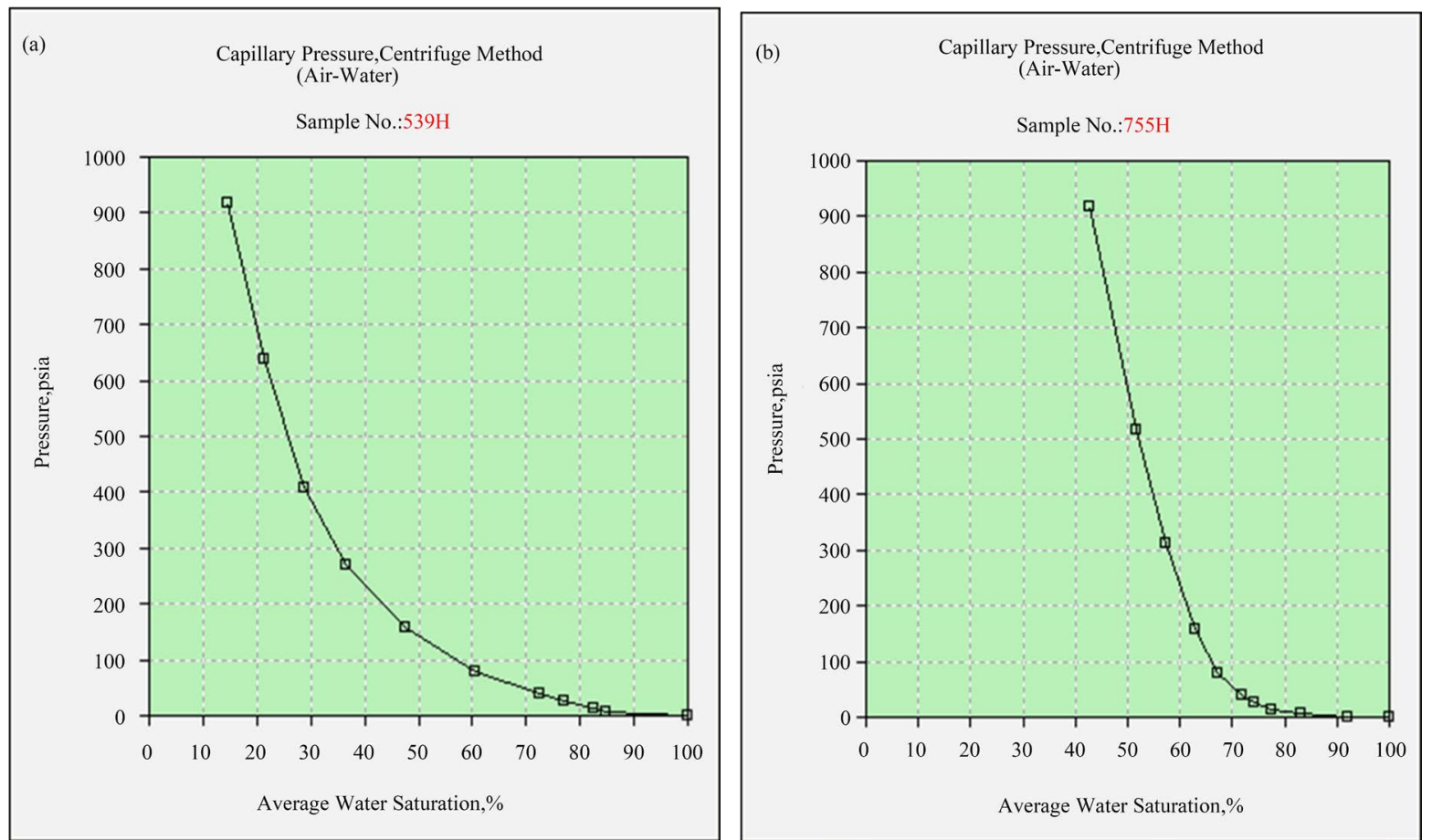

Plot 2. Cross plots show release the amount of water saturated inside the porosities into RRTs vs. the amount of capillary pressure under laboratory conditions. (a). with increasing about $100 \mathrm{psi}$, releases up to $40 \%$ of the water saturated trapped in porosity of the RRTs-3, so must increase capillary pressure up to 900 psi to achieve larger amounts of water saturated. The gentle slope of the plot also shows the problem. Therefore, the permeability of the reservoir rock is not suitable for extraction of hydrocarbons. (b). As can be seen in this plot, with increasing the capillary pressure about 100 psi just $30 \%$ of the water saturated release from porosity of RRTs-4. With increasing the pressure about 900 psi achieves about $40 \%$ of the water saturated. The RRTs-4 having low permeability and high Swir, so this RRTs-4 has not condition of a reservoir rock.
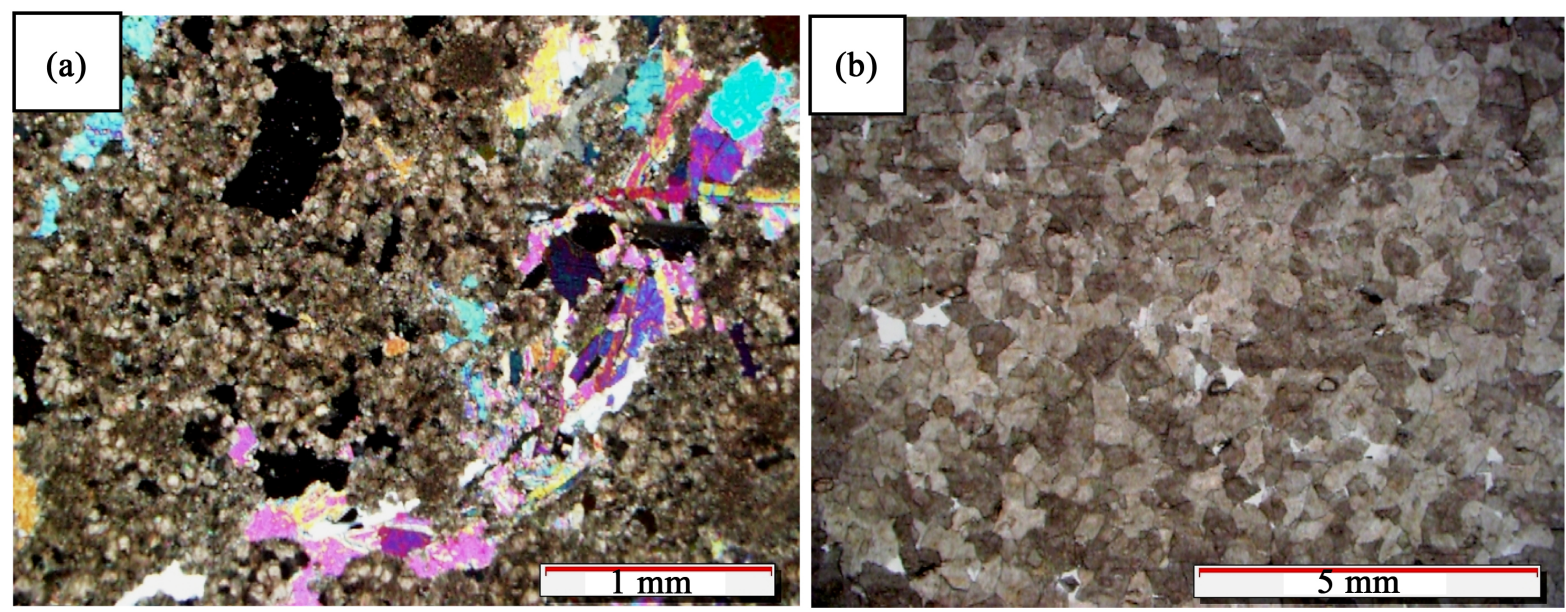

Figure 5. Types of RRTs-3: (a) Dolo-grainstone having vuggy and Intergranular porosities. Some of the porosities are occupied with anhydrite. (b) Dolostone with some intercrystalline porosity (arrow). The rock was over-dolomitized and the most of the porosities has been lost.

\subsection{Rock Type 4 (RRTs-4)}

1) Bioclastic-ooid grainstone: in this rock type, moldic porosity is dominant in comparison with other porosities; however some of the molds are occupied by dolomite, anhydrite and calcite. Spaces between ooids are filled by types of calcite cements and dolomite but there is some interparticle porosity (Figure 6(a)). The rock 

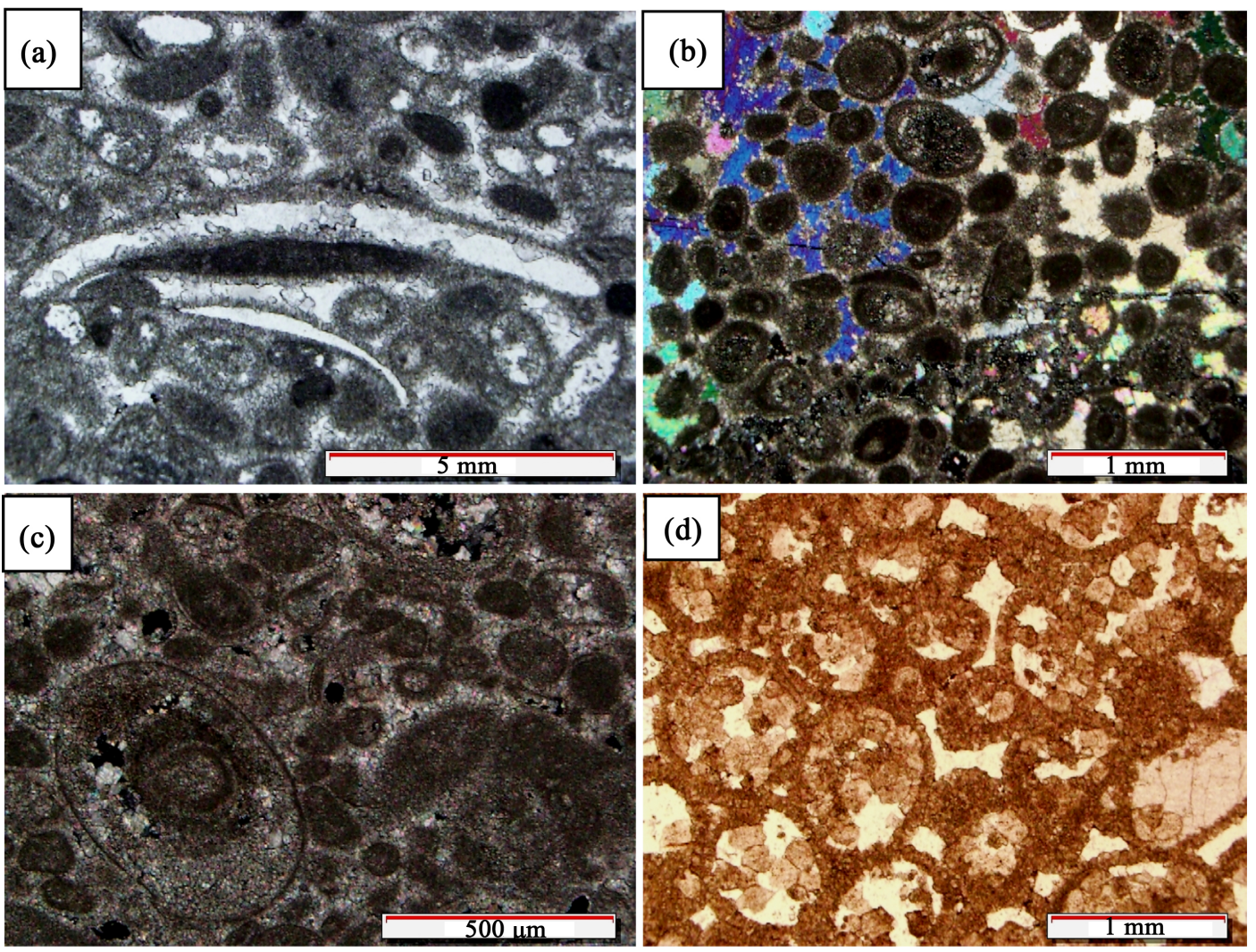

Figure 6. Types of RRTs-4: (a) A grainstone consists of poorly sorted ooids and bivalve accompanied with moldic porosity and some Intergranular porosity. The rock has been under mechanical compaction and ooids are deformed. (b) A grainstone having Intergranular, intragranular, and moldic porosities. All of the porosities are occupied with Poikilotopic anhydrite (light colors). (c) A grainstone consists of poorly sorted ooids and skeletal debris. The most of porosities are occupied with calcite cements. (d) A grainstone having moldic and Intergranular porosities. The most of the porosities was filled with dolomite crystals.

has the highest Swir and lowest permeability (Table 1, row 4 and Plot 2(b)). This rock type is non-reservoir.

2) Ooid-grainstone: A grainstone with interparticle, intraparticle and moldic porosities that all of the spaces in the rock are occupied by anhydrite (Figure 6(b)). Ooids are compacted, poorly sorted and some of them are formless. The rock shows the highest Swir and lowest permeability (Table 1, row 4 and Plot 2(b)). This rock type is non-reservoir.

3) Bioclastic-ooid grainstone: in this grainstone, most of interparticle and intraparticle porosities were filled by calcite cement (Figure 6(c)). The rock consists of poorly sorted skeletal debris and ooids and has the highest Swir and lowest permeability (Table 1, row 4 and Plot 2(b)). This rock type is non-reservoir.

4) Ooid-grainstone: This rock is a grainstone, composed of poorly sorted ooids, moldic and interparticle porosities (Figure 6(d)). Most of ooid molds are occupied by dolomite cements and some of them with anhydrite. Most of interparticle porosity was filled by fine grain dolomites. The rock has the highest Swir and lowest permeability (Table 1, row 4 and Plot 2(b)). This rock type is non-reservoir.

\section{Conclusions}

After determination reservoir rock types of the Upper Dalan Member (Well\#A), it is necessary to study position of the rock types in the litho-stratigraphic column (Figure 2) as follow:

\subsection{RRTs $1 \& 2$}

These rock types are the best and have the highest quality reservoir rocks in the Upper Dalan Member (yellow and green colors). The suitable rocks for reservoir are mostly located in the zone K4 (Figure 2). Other rock 
types (RRTs 3 \& 4) also present in the K4 zone as interlayer. So there is not any integration in the gas reservoir and the reservoir is divided into several sections by RRTs. Each section can acts as a separation barrier. Lthologically, these rock types are mostly composed of crystalline carbonate (dolomite) and grainstone, so dolomitization and brecciaing (probably as a result of salt tectonism in the gas field) could play a very important role in the development of reservoir conditions. It should be noted that dolo-grainstone rocks with intergranular and channel porosities, and dolo-grainstone with intergranular, intragranular, and moldic porosities have also good quality to reservoir (rock type 2, green). The rocks with reservoir quality (yellow and green) are not limited to the K4 and are seen in the K3. As mentioned before, alternations of non-reservoir and reservoir rocks acts as impermeable barriers, lading to stratification of the reservoir. In this part, dolomitization process also had an outstanding impact. In total, the Upper Dalan Member has about 50 meters high quality rock for reservoir.

\subsection{RRTs $3 \& 4$}

These rock types have not conditions for the reservoir rock. By referring to the litho-stratigraphic column (Figure 2) it reveals that these rock types occupy a large part of the K3 zone and small part of the K4 zone (blue and black colors).

In this study, available data sources for the Well\#B are gamma and sonic logs and also lithological information as a litho-stratigraphic column (Figure 2). However, the productivity tests results are also exist. If we assign a number to the each tested zone in Well\#B (green colored area) and correlate this zone with Well\#A, following results are yielded:

\subsection{Zone 1}

After productivity test, it was found that the zone has a gas, gas condensates and a little water (Figure 2). By correlating of this zone with Well\#A it reveals that rock types 1 \& 2 (best reservoir rock) can also be in the Well\#B and probably the dominant porosity in this zone is identical in the both wells. It can be said there are gas and gas condensates in this zone of the formation in the Well\#A.

\subsection{Zone 2}

This zone also contains gas, gas condensate and a little water. By correlating of the zone into Wells\# A is also available. However, appropriate thickness of reservoir rock types in the Well\#A (yellow and green) is decreased, but it can contain hydrocarbon (Figure 2). It means that in this area, diagenesis process damaged the reservoir rocks of Wells\#A, so the quality and quantity of reservoir in the zone have been decreased.

\subsection{Zone 3 \& 4}

Similar to zone 1, these zones are traceable in the both wells (Figure 2). As can be observed in zone 3 , the thickness in Wells\# A is much more than the Well \#B. This is the role of diagenesis in a gas field.

Lithological diversity in the reservoir rock types (RRTs) implies that the latest diagenetic process probably determines the quality of a well or field, not its sedimentary environments.

\section{Acknowledgements}

The authors thank the experts and management of PEDEC (Petroleum Engineering and Development Company of Iran) who provided data preparation. We express our thanks to Islamic Azad University, Science and Research Branch authorities.

\section{References}

[1] Aliakbardoust, E. and Rahimpour-Bonab, H. (2013) Integration of Rock Typing Methods for a Carbonate Reservoir Characterization. J. Geophysics. Eng, 10, 055004.

[2] Choquette, P.W. and Pray, L.C. (1970) Geologic Nomenclature and Classification of Porosity in Sedimentary Carbonates. AAPG Bulletin, 54, 207-250.

[3] Archie, G.E. (1952) Classification of Carbonate Reservoir Rocks and Petrophysical Considerations. AAPG, 36, 278298. 
[4] Lucia, F.J. (1995) Rock-Fabric Petrophysical Classification of Carbonate Pore Space for Reservoir Characterization. American Association of Petroleum Geologists Bulletin, 79, 1275-1300.

[5] Lucia, F.J. (1999) Carbonate Reservoir Characterization. Springer, Berlin. http://dx.doi.org/10.1007/978-3-662-03985-4

[6] Granier, B. (2004) A New Approach in Rock-Typing, Documented by a Case Study of Layer-Cake Reservoirs in Field A, Offshore Abu Dhabi (U.A.E.). Carnets de Géologie/Notebooks on Geology—Article 2003/04 (CG2003_A04_BG), $1-13$.

[7] Skalinski, M. and Kenter, J.A.M. (2013) Carbonate Petrophysical Rock Typing: Integrating Geological Attributes and Petrophysical Properties while Linking with Dynamic Behavior. AAPG Hedberg Conference on Fundamental Controls on Flow in Carbonates, France, 8-13 July 2013, 229-259.

[8] Bagheri, A.M. and Biranvand, B. (2006) Characterization of Reservoir Rock Types in a Heterogeneous Clastic and Carbonate Reservoir. JSUT, 32, 29-38.

[9] Askari, A.A. and Behrouz, T. (2011) A Fully Integrated Method for Dynamic Rock Type Characterization Development in One of Iranian Off-Shore Oil Reservoir. Journal of Chemical and Petroleum Engineering, University of Tehran, 45, 83-96.

[10] Xu, C., Heydari, Z. and Torres-Verdin, C. (2012) Rock Classification in Carbonate Reservoirs Based on Static and Dynamic Petrophysical Properties Estimated from Conventional Well Logs. SPE Annual Technical Conference and Exhibition held in San Antonio, Texas, 8-10 October 2012. http://dx.doi.org/10.2118/159991-MS

[11] Arian, M. (2011) Basement Tectonics and Geology of Iran. Asar-e-Nafis, Qom. (In Persian)

[12] Stampfli, G.M., Borel, G.D., Cavazza, W., Mosar, J. and Ziegler, P.A. (2001) Palaeotectonic and Palaeogeographic Evolution of the Western Tethys and PeriTethyan Domain (IGCP Project 369). IGCP Episode, 24, 222-227.

[13] Agard, P.. Omrani, J., Jolivet, L., Whitechurch, H., Vrielynck, B., Spakman, W., Monie, P., Meyer, B. and Wortel, R. (2011) Zagros Orogeny: A Subduction-Dominated Process. Geological Magazine, 148, 692-725. http://dx.doi.org/10.1017/S001675681100046X

[14] Anovitz, L.M. and Cole, D.R. (2015) Characterization and Analysis of Porosity and Pore Structures. Reviews in Mineralogy \& Geochemistry, 80, 61-164. http://dx.doi.org/10.2138/rmg.2015.80.04

[15] Dernaika, M., Uddin, Y. N., koronfol, S., Al Jallad, O. and Sinclair, G. (2015) Multi-Scale Rock Analysis for Improved Rock Typing in Complex Carbonates. International Symposium of the Society of Core Analysts, Newfoundland and Labrador, Canada, 16-21 August 2015, 1-6.

[16] Lucia, F.J. (2007) Carbonate Reservoir Characterization: An Integrated Approach. 2nd Edition, Springer-Verlag, Heidelberg.

[17] Simo, J.A., Johnson, C.M., Vandrey, M.R., Brown, P.E., Castrogiovanni, E., Drzewiecki, P.E., Valley, J.W. and Boyer, J. (1994) Burial Dolomitization of the Middle Ordovician Glenwood Formation by Evaporitic Brines, Michigan Basin. Special Publications of International Association of Sedimentologists, 21, 169-186.

\section{Submit or recommend next manuscript to SCIRP and we will provide best service for you:}

Accepting pre-submission inquiries through Email, Facebook, Linkedin, Twitter, etc

A wide selection of journals (inclusive of 9 subjects, more than 200 journals)

Providing a 24-hour high-quality service

User-friendly online submission system

Fair and swift peer-review system

Efficient typesetting and proofreading procedure

Display of the result of downloads and visits, as well as the number of cited articles

Maximum dissemination of your research work

Submit your manuscript at: http://papersubmission.scirp.org/ 